\title{
Non-Chemical Weed Management in Vegetables by Using Cover Crops: A Review
}

\author{
Husrev Mennan ${ }^{1, *}$, Khawar Jabran ${ }^{2}$, Bernard H. Zandstra ${ }^{3}$ and Firat Pala 4 \\ 1 Department of Plant Protection, Agriculture Faculty, Ondokuz Mayis University, 55139 Samsun, Turkey \\ 2 Department of Plant Production and Technology, Faculty of Agricultural Science and Technologies, Nigde \\ Omer Halisdemir University, 51240 Nigde, Turkey; khawarjabran@gmail.com \\ 3 Department of Horticulture, Michigan State University, East Lansing, MI 48824, USA; zandstra@msu.edu \\ 4 Department of Plant Protection, Agriculture Faculty Siirt University, 56100 Siirt, Turkey; firatpala@gmail.com \\ * Correspondence: hmennan@omu.edu.tr; Tel.: +90-362-3121919
}

Received: 4 December 2019; Accepted: 5 February 2020; Published: 11 February 2020

check for updates

\begin{abstract}
Vegetables are a substantial part of our lives and possess great commercial and nutritional value. Weeds not only decrease vegetable yield but also reduce their quality. Non-chemical weed control is important both for the organic production of vegetables and achieving ecologically sustainable weed management. Estimates have shown that the yield of vegetables may be decreased by $45 \%-95 \%$ in the case of weed-vegetable competition. Non-chemical weed control in vegetables is desired for several reasons. For example, there are greater chances of contamination of vegetables by herbicide residue compared to cereals or pulse crops. Non-chemical weed control in vegetables is also needed due to environmental pollution, the evolution of herbicide resistance in weeds and a strong desire for organic vegetable cultivation. Although there are several ways to control weeds without the use of herbicides, cover crops are an attractive choice because these have a number of additional benefits (such as soil and water conservation) along with the provision of satisfactory and sustainable weed control. Several cover crops are available that may provide excellent weed control in vegetable production systems. Cover crops such as rye, vetch, or Brassicaceae plants can suppress weeds in rotations, including vegetables crops such as tomato, cabbage, or pumpkin. Growers should also consider the negative effects of using cover crops for weed control, such as the negative allelopathic effects of some cover crop residues on the main vegetable crop.
\end{abstract}

Keywords: cover crops; weeds; vegetables; non-chemical weed control; allelopathy; physical weed control

\section{Introduction}

Several production problems diminish the quality and yield of vegetables. Salinity, drought stress and climate changes are a few abiotic factors that decrease the yield of vegetables while the major biotic factors that reduce the yield include disease pathogens, insect pests, viruses, and weeds [1]. The yield losses caused by unchecked weeds in vegetable production systems may be between 45 to $95 \%$ depending on the production environment [2]. Despite the common use of herbicides in the USA, the loss in value of certain vegetables due to weeds ranged between $8 \%$ to $13 \%$ [3]. Weeds not only reduce the yield of vegetables but also decrease their quality and market value [4].

Chemical weed control has been a great option in conventional vegetable production systems because it provides effective and sustainable weed control. However, overuse of herbicides causes environmental concerns because herbicides have negative effects on non-target organisms (beneficial species), may pollute the food and groundwater with their residue, and cause toxicity in mammalians $[5,6]$. There has been a greater interest in non-chemical weed control after people became more aware of the damage caused by the misuse of herbicides [7]. 
Weeds in either organic or conventional vegetable production systems can be controlled through hand hoeing or mechanical cultivation. Inter-row cultivation has a proven usefulness for controlling weeds in vegetable production systems but the high cost of fuel may constrain this practice. Moreover, the practice of inter-row cultivation may accelerate soil erosion [8-10]. Programmed weed-controlling robots have potential for the automation of weed management operations. However, because the technology is expensive, it still needs some time to be adopted by the vegetable growers. The root system of vegetables may be damaged by the hand-hoeing, and this practice is labor-intensive and costly $[7,11,12]$.

Organic and conventional vegetable productions need effective weed control strategies. The use of cover crops for allelopathic and physical weed control is among the effective strategies [13-16]. Cover crops can be considered as effective tools to suppress weeds in vegetable fields $[14,17]$. Cover crops can act as an alternative to tillage for controlling weeds and reducing yield losses caused by weeds [18]. Cover crops are not grown as a cash crop but rather are grown for several of their ecological benefits. Some of the synonyms used for cover crops are living mulch, catch crop, smother crop and green manure. These can be grown during fallow periods, along with the main cash crop or during a part of the growing season of a cash crop. The ecological benefits of cover crops are not limited to improvements in soil fertility, soil conservation or pest suppression. Cover crops modify the microclimate of the companion crop by intercepting sun radiation, provide a habitat for beneficial biological agents, such as insects that prey on weeds or other detrimental insects, modify the energy of raindrops and play a role in the uniform distribution of precipitation in the soil. Besides those features, cover crops may decrease erosion, conserve soil moisture, increase soil fertility and improve its structure. Negatively, sometimes cover crops may also facilitate/promote some pests and, if not removed prior to the critical period for weed control of the companion crop, can themselves act as weeds and reduce crop yield [19].

Previous research shows that cover crops can be grown for weed control in various agricultural systems [20-22]. Many cover crops have been investigated in different parts of the world and have shown good results. For example, cover crops such as fodder radish (Raphanus sativus L.), vetch (Vicia spp.), rye (Secale cereale L.) or their appropriate combinations can provide effective weed control in no-till organic crop production systems [23]. S. cereale with allelopathic potential decreased the barnyard grass (Echinochloa crus-galli (L.) P. Beauv.) leaf count and dry biomass [24]. A number of review articles are available that address various aspects of cover crops. Nevertheless, to the best of our knowledge, no review article addresses the use of cover crops for achieving non-chemical weed control in vegetable crops. Hence, in this review paper, we have reviewed the literature to explain the yield losses caused by weeds in the vegetables, the need for non-chemical weed control in vegetables, the use of cover crops for weed control in vegetables and the disadvantages of the cover crops.

\section{Yield Losses Caused by Weeds in Vegetable Crops}

Weeds are a significant issue in the production of vegetables. Several factors affect the degree of vegetable yield reduction and damage to quality caused by weeds. The most important of these are the competitiveness of the vegetable plants with the infesting weeds, the relative densities of weeds and vegetable plants, weed emergence time, and the competition duration [25-27]. Vegetables planted either as seeds or seedlings are weak competitors because of their shallow root system and sluggish growth, especially during the early stages. Hence, the vegetables are highly sensitive to weed competition and need to be kept weed-free during that early growth stage. The yield losses caused by weeds in various vegetables have been reported in previous studies. For example, weed cover in pea (Pisum sativum L.) was $73 \%$ if it was grown without any cover crop, i.e., without any weed control practice [28]. Decrease in yield of lettuce (Lactuca sativa L.) because of weed competition has been reported in previous studies [29]. In a study from England, a density of 65 weeds $\mathrm{m}^{-2}$, including a mixture of broadleaf and narrow leaved weeds, could completely destroy the lettuce crop [29]. Similarly, a study from California showed that lettuce-weed competition for the whole growing season 
decreased the yield by $50 \%$ [30]. In Florida, a season-long lettuce-weed competition reduced the yield of lettuce by $56 \%$ [31]. Besides the yield reduction, the quality of lettuce is also reduced due to weed competition [32]. Similarly, weed competition in soybean (Glycine max (L.) Merr.) during the first (v1) and third foliates (v3) stages (according to $\mathrm{BBCH}$ ) was critical in damaging the crop plant development [33].

Similarly, in pepper (Capsicum annuum L.), weeds such as purple nutsedge (Cyperus rotundus L.) could decrease the fruit yield by up to $44 \%$ [34]. In another study, the fruit number of the bell pepper (C. annum) was decreased by $94 \%$ if its growth was interfered with by the weed Palmer amaranth (Amaranthus palmeri (S.) Wats.) [16]. Moreover, a weed-free period of 12.2 weeks was needed by chili pepper (C. annum) to avoid a yield decrease of more than 5\% [35]. Yield of the tomato (Solanum lycopersicum L.) was decreased by $48 \%-71 \%$ when the vegetable plants were growing in competition with weeds such as large crabgrass (Digitaria sanguinalis (L.) Scop.), tall morning glory (Ipomoea purpurea (L.) Roth), common cocklebur (Xanthium strumarium L.), and jimsonweed (Datura stramonium L.) [36].

\section{Need for Non-Chemical Weed Control in the Vegetable Crops}

Non-chemical weed control is desired for several reasons. The development of modern vegetable production systems is likely to be slowed if weed management options are limited [37]. The availability of non-chemical weed control methods along with weed control with herbicides will increase the likelihood of achieving sustainable weed control in vegetable production systems. Furthermore, there is a strong demand for organic foods, particularly for vegetables globally, and this organic vegetable production is not possible without non-chemical weed control [38].

Herbicide-resistant weeds in vegetable production systems also stress the need for non-chemical weed control [39]. Similarly, the misuse of herbicides causes environmental pollution, and non-chemical weed control should be available as an additional choice for sustainable weed control $[7,40]$.

\section{Types of Cover Crops}

Cover crops could be classified into four groups based on their taxonomy. Table 1 gives a comprehensive list of cover crops that have been used for controlling weeds in vegetables and other crops, and for achieving other ecological benefits. According to this classification, there are grasses, legumes, Brassicaceae plants, and others. Important examples of grass cover crops are ryegrass (Lolium multiflorum Lam.), barley (Hordeum vulgare L.), and sorghum (Sorghum spp.). R. sativus and mustards (Sinapis spp.) are important in the Brassicaceae plants. Similarly, beans (Phaseolus spp.), vetches (Vicia spp.) and peas (Pisum spp.) are important pulses that are grown as cover crops (Table 1). Growers may select a few of these cover crop species, considering their specific farm situations. For example, they may avoid using legumes and prefer cereal cover crops if the soil is rich in nitrogen or has nitrogen residue from the previous crop. On the other hand, legume cover crops may be preferred if the soil has less nitrogen [41].

Table 1. A list of important cover crops used for weed control and other ecological advantages.

\begin{tabular}{cll}
\hline Cover Crop Type & Name of Cover Crop & Reference \\
\hline & Bristle oat (Avena strigosa) & {$[42]$} \\
& Winter rye (Secale cereale) & {$[43]$} \\
& Oat (Avena sativa) & {$[43]$} \\
& Sudangrass (Sorghum $\times$ sudanense) & {$[44]$} \\
& Wheat (Triticum aestivum) & {$[44]$} \\
\hline \multirow{4}{*}{ Legumeals } & Pea (Pisum sativum) & {$[45]$} \\
& Cowpea (Vigna unguiculata) & {$[44]$} \\
& Subterranean clover (Trifolium subterraneum) & {$[45]$} \\
& Crimson clover (Trifolium incarnatum) & {$[45]$} \\
& Egyptian clover (Trifolium alexandrinum ) & {$[45]$} \\
\hline
\end{tabular}


Table 1. Cont.

\begin{tabular}{cll}
\hline Cover Crop Type & Name of Cover Crop & Reference \\
\hline & Red clover (Trifolium pratense) & {$[45]$} \\
& Sunn hemp (Crotalaria juncea) & {$[45]$} \\
& Velvet bean (Mucuna pruriens) & {$[45]$} \\
Legumes & Soybean (Glycine max) & {$[45]$} \\
& Faba bean (Vicia faba) & {$[45]$} \\
& Hairy vetch (Vicia villosa) & {$[43]$} \\
& Common vetch (Vicia sativa) & {$[46]$} \\
\hline \multirow{3}{*}{ Brassicaceae plant } & Forage radish (Raphanus sativus) & {$[42]$} \\
& Rapeseed, canola (Brassica napus) & {$[45]$} \\
& White mustard (Sinapis alba) & {$[45]$} \\
\hline \multirow{3}{*}{ Non-legumes } & Buckwheat (Fagopyrum esculentum) & {$[42]$} \\
& Flax (Linum usitatissimum) & {$[42]$} \\
& Niger (Guizotia abyssinica) & {$[42]$} \\
\hline
\end{tabular}

\section{How Cover Crops Suppress the Weeds?}

Suppression of weeds through cover crops is dependent on several factors and a selective weed control is offered by some cover crops [13,42-46]. Therefore, cereal, legume and brassicaceae cover crops are widely used in various cropping systems.

Weed suppression through cover crops is achieved by more than a single action. Importantly, both competition and allelopathy have been assumed as mechanisms of weed suppression by cover crops $[46,47]$. One important mechanism of action of a cover crop is its physical effect on weeds. Most of the studies on the effects of cover crops on weeds essentially consider the quantity of accumulated cover crop biomass [48]. A cover crop with high biomass production is likely to produce a good physical effect on weeds, and hence result in effective weed suppression. Early-season total biomass accumulation by cover crops reduces the risk of weed emergence (Figures 1 and 2) [49,50]. The grass cover crops L. multiflorum, A. sativa, and S. cereale had a higher biomass than the other cover crops and suppressed the weeds effectively (Figures 3 and 4).

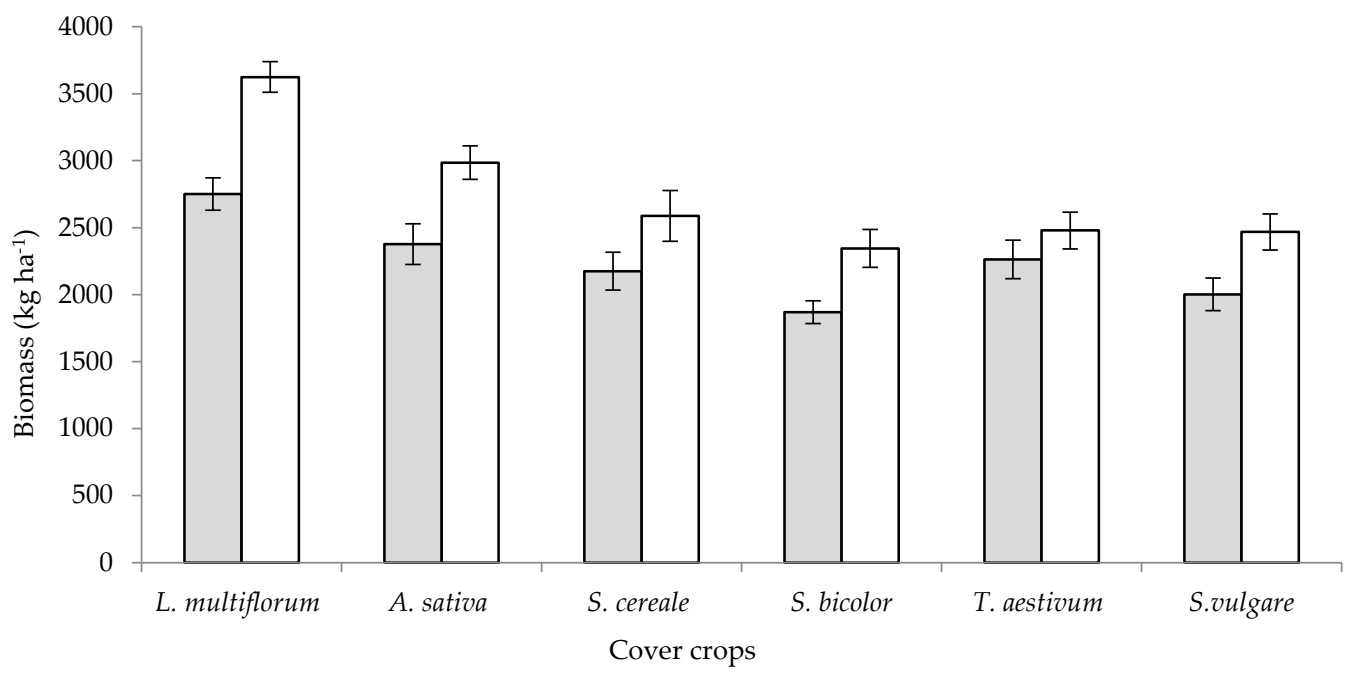

Figure 1. Biomass production $\left(\mathrm{kg} \mathrm{ha}^{-1}\right)$ of cereal cover crops in different vegetable production systems prior to termination in 2005 (gray bars) and 2006 (white bars). Vertical lines represent standard errors of the means $(p<0.05)[49,50]$. 


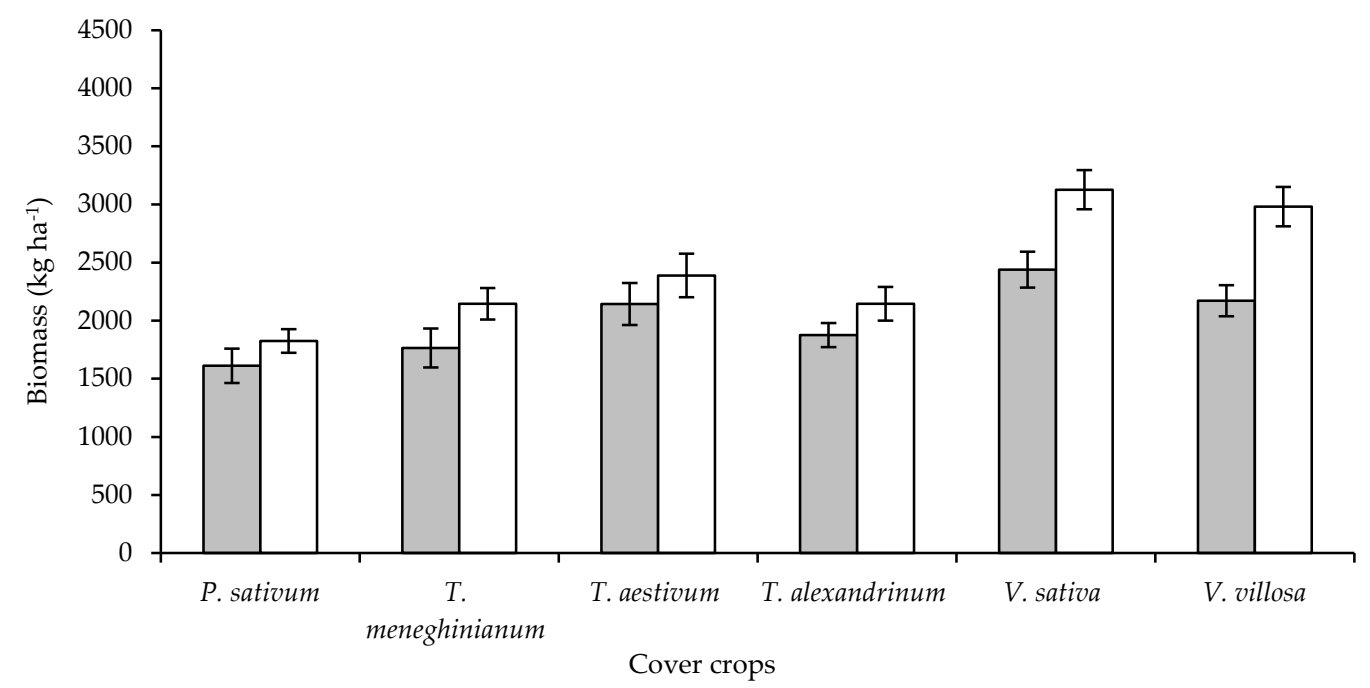

Figure 2. Biomass production $\left(\mathrm{kg} \mathrm{ha}^{-1}\right)$ of cover crops in different vegetable production systems prior to termination in 2005 (gray bars) and 2006 (white bars). Vertical lines represent standard errors of the means $(p<0.05)[49,50]$.

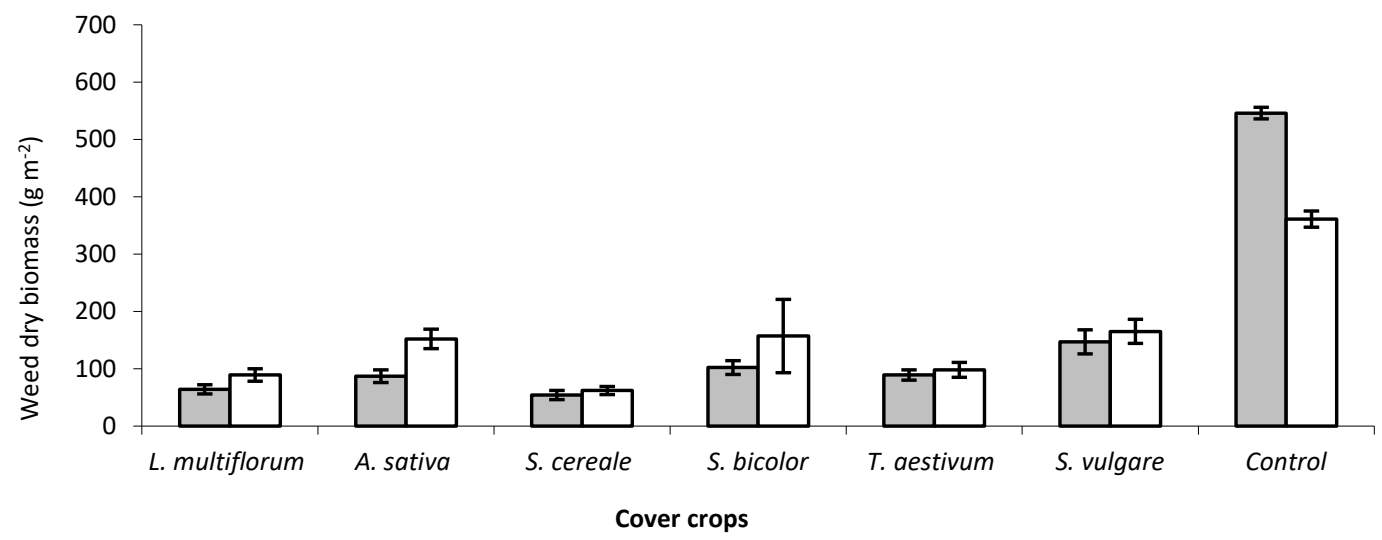

Figure 3. Effects of various cereal cover crops in different vegetable production systems on the dry biomass production $\left(\mathrm{g} \mathrm{m}^{-2}\right.$ ) of weed species at the time of cover crop termination in 2005 (gray bars) and 2006 (white bars). Vertical lines represent standard errors of the means $(p<0.05)[49,50]$.

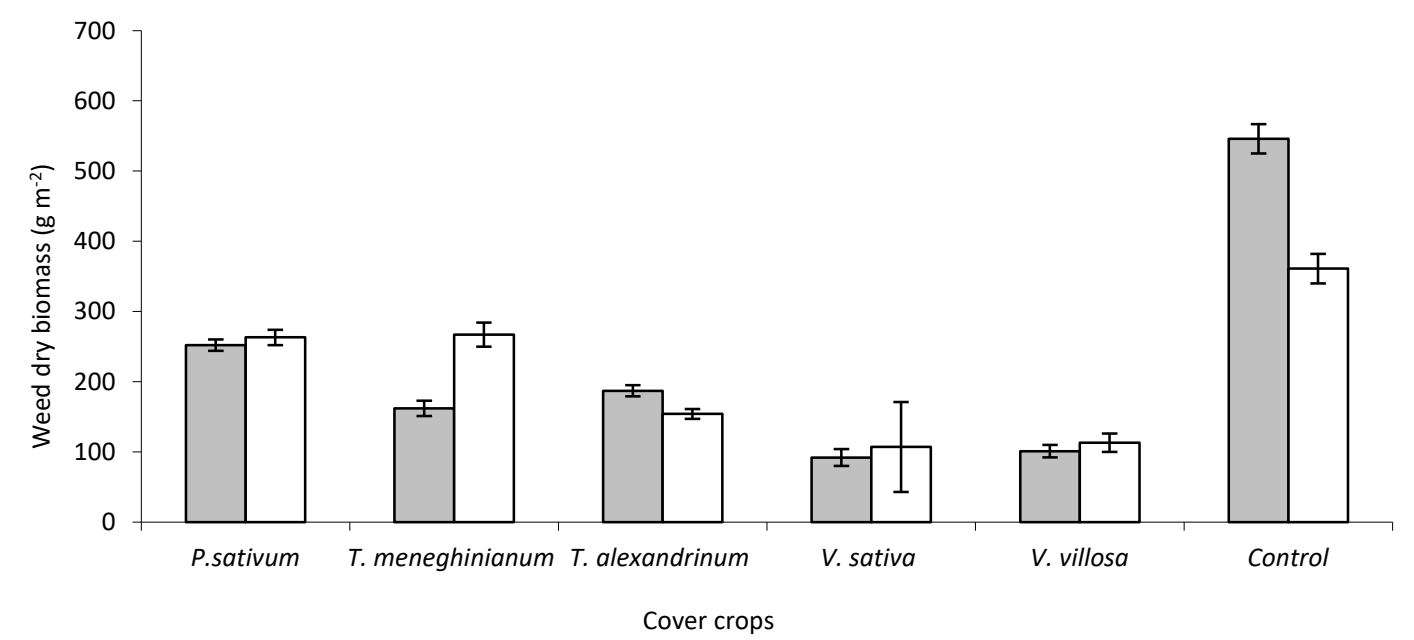

Figure 4. Effects of various legume cover crops in different vegetable production systems on the dry biomass production $\left(\mathrm{g} \mathrm{m}^{-2}\right.$ ) of weed species at the time of cover crop termination in 2005 (gray bars) and 2006 (white bars). Vertical lines represent standard errors of the means $(p<0.05)[49,50]$. 
The biomasses of L. multiflorum, A. sativa, and V. sativa species were recorded as having the highest values (Figure 1). On the other hand, the biomasses accumulated by P. sativum, S. bicolor, and ball clover (Trifolium meneghinianum Clementi) species were recorded as the lowest values, respectively. Cover crops had a stronger impact on the biomass of weeds than on their density. Even if weeds were found in a high number after a cover crop, there was a greater decrease in their biomass [51]. Sometimes, a mixture of cover crops may perform better than a single crop, but this may not always be the case. A comparison of S. cereale, hairy vetch (Vicia villosa Roth), and a S. cereale-V. villosa combination showed that $S$. cereale was the best weed suppressor cover crop and the mixture of $S$. cereale-vetch was similar to the S. cereale cover crop [51].

A statistical relationship (correlation) has also been consistently described for the quantity of cover crop biomass and the extent of weed suppression (Figures 3 and 4). A cover crop biomass of $8 \mathrm{tha}^{-1}$ or higher may be enough to achieve a satisfactory and sustainable weed suppression [48]. For instance, forage radish is an important cover crop and its weed-suppressing mechanism has been reported previously [52]. Rapid canopy development and other weed-competitive traits of forage radish were found to be a cause of weed suppression and allelopathy was found to have no role [52]. Generally, early soil coverage and a high seeding rate of cover crops can increase pressure on weeds. Growing a cover crop with a higher seeding density means producing more biomass of cover crop; this will ultimately suppress more weeds [53]. S. cereale cover crop seeding rates did not affect the weed emergence, but a high cover crop dry biomass produced a high seeding rate that decreased the weed biomass [54].

Weed dry biomasses because of the application of cover crops, including P. sativum, T. meneghinianum, and T. alexandrinum species, were recorded as having the highest values after the value of control plots (Figures 3 and 4). On the other hand, the dry biomass of L. multiflorum, S. cereale and T. aestivum species were recorded as having the lowest values, respectively.

The density of weeds in sudangrass (Sorghum vulgare), S. bicolor, and T. aestivum were recorded as having the highest values after the value of control plots (Figure 5). On the other hand, the weed density of L. multiflorum, A. sativa, and S. cereale were recorded as having the lowest values, respectively.

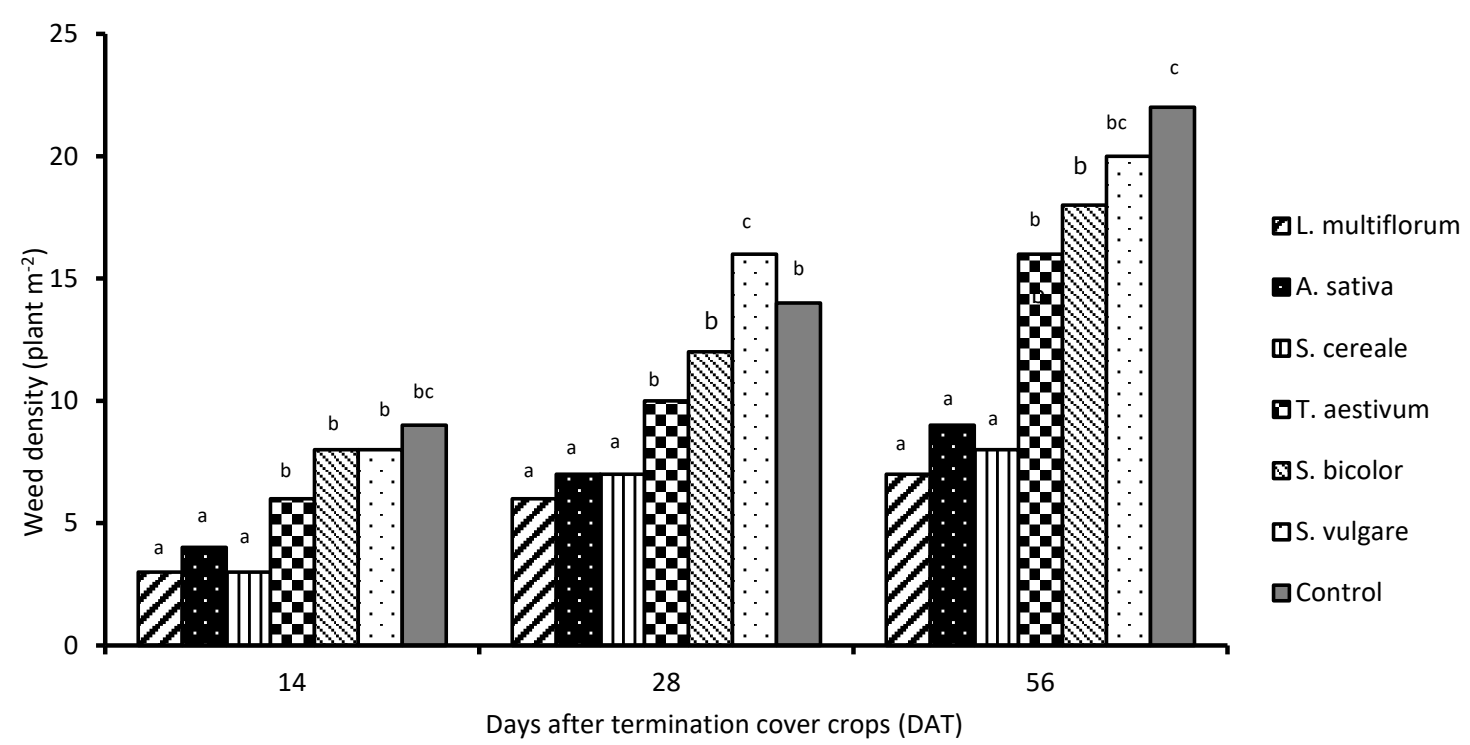

Figure 5. Effects of various cereal cover crops in different vegetable production systems on weed density after different time of cover crop termination. Vertical lines represent standard errors of the means $(p<0.05)[49,50]$.

Several other mechanisms exist that help the cover crops to suppress weeds in vegetable crops. For instance, competition for space between living cover crops and weeds reduces the space for weeds. Shading is the other mechanism through which cover crops are likely to suppress weeds in vegetable 
crops. Further, the cover crops alter the light quality that is likely to influence the development of weeds [55]. For example, far-red light reflection causes developmental changes in weeds that reduces their biomass and seed production [56]. Some cover crops induce the germination of weed seeds, and hence cause a depletion of the weed seed bank; e.g., a mixture of S. cereale, buckwheat (Fagopyrum esculentum Moench), and yellow mustard (Brassica juncea (L.) Czern.) grown as a cover crop helped to completely deplete Setaria spp. in the weed seed bank, and caused an $80 \%-85 \%$ decrease in the germinable seed bank of velvetleaf (Abutilon theophrasti Medik.) and common lambsquarters (Chenopodium album L.) [57]. The long-term practicing of cover cropping results in a reduction in the weed seed bank in the soil [58]. Earlier emergence of a cover crop may enable it to cause a high suppression of weeds [59]. The weed dry biomass in organically grown vegetables was inversely proportional to the seeding rates of legumes (e.g., V. faba, P. sativum) and cereal (A. sativa) [60].

The allelopathic potential of cover crops is the other important method through which cover crops suppress weeds (Table 2). S. cereale is among the most effective and important cover crops and its allelopathic potential has been reported consistently in the literature [61-63]. S. cereale varies in the concentration of allelochemicals and, hence, the effect on weeds. The cultivars varied in their content of benzoxazinoides, while weeds had a variable uptake of allelochemicals that caused some weeds to be more sensitive to cover crops. For example, in greenhouse and field experiments, redroot pigweed (Amaranthus retroflexus L.) and common purslane (Portulaca oleraceae L.) showed a greater response to S. cereale cover mulches than C. album [64]. Allelochemicals such as DIBOA, BOA, DIBOA-glucoside, and AZOB have been reported from S. cereale plants, and the persistence of these allelochemicals in the soil had a correlation with the accomplished level of weed control $[47,65,66]$.

Plants from the Brassicaceae family are an important cover crop group for weed suppression. Glucosinolates are important allelochemicals that are present in brassica species and may have a role in the weed control activity [67]. Brassica cover crops exude these glucosinolates to the soil environment, where they are converted to their active form, i.e., isothiocyanates. For instance, six allelochemicals (isothiocyanates) were identified in field mustard (Brassica rapa L.); these were 2-phenylethyl-ITC, n-butyl, 3-butenyl, benzyl, allyl, and 4-pentanyl [68]. Previous studies have described the allelopathic effects of cover crops on weeds. Weeds such as C. album and wild foxtail millet (Setaria media (L.) Vill.) were suppressed by $60 \%$ by cover crops such as white mustard (Sinapis alba), R. sativus, V. sativa and the mixture of these cover crops suppressed the weeds by 66\% [69]. In many instances, it may be difficult to quantify the exact mechanism of weed suppression by cover crops. In such cases, both competition and allelopathy, or any of these, may be involved. For example, the cover crops decrease the emergence of weed seedlings, expansion of the weed canopy and biomass production by weeds, and this was achieved either through physical effect or allelopathy [70].

There is particular significance in using cover crops for weed control in no-till systems. In conventional vegetable production systems, the weeds are controlled by using tillage as a tool along with other weed control methods, such as herbicide applications. However, no-till vegetable production has been popular in recent years due to associated benefits such as environmental and resource conservation, and cost-effectiveness. Growing vegetables in the no-till system limits the weed control options as it restricts the use of tillage, which is a practice primarily carried out for seedbed preparation and weed control. Cover crops are an excellent option to control weeds in no-till vegetable systems. Cover crops also conserve the soil and water and promote a healthy environment for sustainable vegetable production.

Another important question that arises in the use of cover crops is the persistence of allelopathic substances in soil and according activity levels. Soil factors can modify the allelopathic activity of cover crops in the soil; the most important of these factors are the ion-exchange capacity of the soil, the concentration of organic matter in it and the biotic content [79]. For example, phenolic acid concentrations may reach a maximum after 10-15 days of cover crop incorporations and may remain effective until 20-25 days [80]. This cover crop residue inhibits the germination of weed seeds and decreases the weed density, but their effects are active for a short time and the weeds often reemerge [81] (Table 3). 
Table 2. Allelochemicals reported in various cover crops.

\begin{tabular}{clc}
\hline Cover Crop & \multicolumn{1}{c}{ Allelochemicals } & Reference \\
\hline Rye (Secale cereale) & MBOA, BOA, HMBOA, DIBOA & {$[71]$} \\
\hline Barley (Hordeum vulgare) & $\begin{array}{l}\text { Gramine, hordenine, p-hydroxybenzoic acid, vanillic } \\
\text { acid, p-coumaric acid, syringic acid, ferulic acid }\end{array}$ & {$[72,73]$} \\
\hline Sorghum (Sorghum bicolor) & $\begin{array}{l}\text { Sorgoleone, m-coumaric acid, caffeic acid, } \\
\text { chlorogenic acid }\end{array}$ & {$[74]$} \\
\hline \multirow{2}{*}{ Wheat (Triticum aestivum) } & $\begin{array}{l}\text { DIMBOA, 2,4-Dihydroxy-1,4-benzoxazine-3-one } \\
\text { (DIBOA) }\end{array}$ & [75] \\
\cline { 2 - 3 } & $\begin{array}{l}\text { DIMBOA, syringic acid, vanillic acid, } \\
\text { p-hydroxybenzoic acid, cis-ferulic acid, trans-ferulic } \\
\text { acid, trans-p-coumaric acid, cis-p-coumaric acid }\end{array}$ & {$[$ [76] } \\
\hline Field mustard (Brassica rapa) & 2-Phenylethyl-isothiocyanate & {$[67]$} \\
\hline Rapeseed (Brassica napus) & $\begin{array}{l}\text { Glucosinolates, 2-Phenylethyl-isothiocyanate, benzyl } \\
\text { isothiocyanate, allyl isothiocyanate, 3-butenyl } \\
\text { isothiocyanate, }\end{array}$ & {$[77,78]$} \\
\hline Field mustard (Brassica campestris) & $\begin{array}{l}\text { Benzyl isothiocyanate, allyl isothiocyanate, 3-butenyl } \\
\text { isothiocyanate }\end{array}$ \\
\hline
\end{tabular}

Table 3. Cover crops with an allelopathic potential and the weeds suppressed by cover crops.

\begin{tabular}{|c|c|c|}
\hline Cover Crop & Weeds Suppressed & References \\
\hline Wheat (Triticum aestivum) & $\begin{array}{l}\text { Ipomoea lacunose, Eleusine indica, } \\
\text { Amaranthus palmeri }\end{array}$ & [82] \\
\hline Rye (Secale cereale) & $\begin{array}{l}\text { Eleusine indica, Amaranthus palmeri, } \\
\text { Ipomoea lacunosa }\end{array}$ & [82] \\
\hline Rye (Secale cereale) & Chenopodium album, Abutilon theophrasti & [83] \\
\hline $\begin{array}{l}\text { Annual ryegrass (Lolium multiflorum), rye } \\
\text { (Secale cereale), bristle oat (Avena strigosa), } \\
\text { common vetch (Vicia sativa), radish }\end{array}$ & $\begin{array}{l}\text { Brachiaria plantaginea, Bidens pilosa, } \\
\text { Euphorbia heterophylla }\end{array}$ & [23] \\
\hline $\begin{array}{l}\text { Hairy vetch (Vicia villosa), oat } \\
\text { (Avena sativa) }\end{array}$ & $\begin{array}{l}\text { Digitaria sanguinalis, Eleusine indica, Amaranthus } \\
\text { retroflexus, Datura stramonium }\end{array}$ & {$[84]$} \\
\hline $\begin{array}{l}\text { Sorghum sudangrass (Sorghum bicolor } \times \\
\text { Sorghum sudanense) }\end{array}$ & Broad leaved weeds & {$[85]$} \\
\hline $\begin{array}{l}\text { Bristle oat (Avena strigosa), hairy vetch } \\
\text { (Vicia villosa) }\end{array}$ & $\begin{array}{c}\text { Amaranthus palmeri, Portulaca oleracea, } \\
\text { Helianthus annuus }\end{array}$ & {$[86]$} \\
\hline $\begin{array}{l}\text { Rye (Secale cereale), hairy vetch (Vicia } \\
\text { villosa), barley }(\text { H. vulgare }) \times \text { triticale, } \\
\text { Austrian winter pea (Pisum sativum) }\end{array}$ & $\begin{array}{c}\text { Chenopodium album, Amaranthus hybridus, } \\
\text { Thlaspi arvense, Taraxacum officinale, Stellaria } \\
\text { media, Elymus repens, Panicum crus-galli, } \\
\text { Setaria glauca }\end{array}$ & [87] \\
\hline White mustard (Sinapis alba) & Amaranthus blitoides, Chenopodium album & [88] \\
\hline $\begin{array}{l}\text { Hairy vetch (Vicia villosa), subterranean } \\
\text { clover (Trifolium subterraneum), oat (Avena } \\
\text { sativa)/hairy vetch (Vicia villosa) }\end{array}$ & Amaranthus retroflexus, Chenopodium album & {$[89,90]$} \\
\hline
\end{tabular}

\section{Disadvantages of Using Cover Crops for Weed Control in Vegetable Production Systems}

Although cover crops can repress weeds and have additional ecosystem benefits, some negative aspects of using cover crops in vegetable production systems have also been noted. For example, some of the cover crops may promote some insect pests or disease pathogens [91]. Moreover, as vegetables have a different morphology and growth habit to other arable crops, there are chances that cover crops, 
along with weeds, may also compete with vegetable crops. Hence, a careful management plan is required when cover crops are to be used for weed control in vegetables [92].

Cover crops may not always provide effective control of weeds in vegetables, i.e., negative or no effects of cover crops in vegetables have also been noted. For example, forage soybean was used as a cover crop in collard (Brassica oleracea L.) vegetables; the cover crop was ineffective in controlling weeds [93]. Moreover, cover crops may occasionally have a positive effect on germination or seedling growth of weeds [94]. Additionally, some shortfalls of cover crops as a weed control technique are also on record. For example, cover crops may not be effective in controlling intra-row weeds; this is because neither their allelopathic effects nor shading effect reaches the intra-rows. This may also be the reason that cover crops usually damage only the weeds and not the crops $[95,96]$. Through the use of cover crops in vegetables, annual weeds are easily controlled, but perennials generally receive a lower impact while sedges are difficult to control [97]. Other research work also showed that cover crops may have weak effectiveness against perennial weeds such as nutsedges (Cyperus spp.) $[47,58]$

Another important aspect is that high biomass production (in order to gain greater weed suppression) may disturb the seeding operation, crop establishment and other crop management operations [98]. Similarly, allelochemicals from cover crops can pose a negative effect on the main vegetables along with their effects on weeds [64]. A well-established practice is to grow cover crops and then desiccate these through some means (e.g., herbicide application, mechanical incorporation). The residue cover crop suppresses the weeds in the next season crop; however, there is a likeliness that this cover crop residue will also negatively affect the germination and seedling growth of the main crop. For example, the germination, seedling emergence or establishment of spinach (Spinacia oleracea L.) and lettuce were negatively affected by the allelopathic activity of two important cover crops, S. cereale and winter oilseed rape (Brassica napus L.) [94]

\section{Cover Crops for Weed Control in Vegetable Crops}

Cover crops are now commonly used in organic vegetable production systems in some parts of the world [97]. For example, growing legumes and grass cover crops in the mixture (e.g., growing $S$. cereale in mixture with soybean, using both as cover crops) is likely to decrease the seed production by weeds, and hence a reduced weed seed bank is expected with this kind of cover crop application [98].

Cover crop mulches in vegetable production systems of the United States could provide fields free of weeds: important cover crops were oilseed radish (Raphanus sativus L.), S. alba and B. juncea [99]. Similarly, legume cover crops velvetbean (Mucuna deeringiana (Bort) Merr.), jumbiebean (Leucaena leucocephala (Lam.) de Wit), jackbean (Canavalia ensiformis (L.) DC.)] are traditionally used in Mexico for controlling weeds in field crops and achieving other ecological benefits of cover crops, such as improved soil fertility [100].

A number of mulches-V. villosa, Egyptian clover (T. alexandrinum L.), A. sativa, T. meneghinianum, wheat (Triticum aestivum L.), S. cereale, V. sativa, L. multiflorum-were tested for their weed control efficacy in tomato [49]. The cover crops were killed before transplanting tomato seedlings. Out of the tested mulches, two mulches, i.e., L. multiflorum and S. cereale decreased the weed biomass by more than 75\%. Two of the other of mulches ( $V$. sativa and $V$. villosa) were also effective for weed control in tomato [49]. Similarly, $V$. villosa as a cover crop in tomato produced a biomass of $7.49 \mathrm{t} \mathrm{ha}^{-1}$, and the mulch from this cover crop decreased the biomass of some weed species (A. retroflexus, D. sanguinalis, P. oleracea) by $40 \%$, and their density by $>70 \%$ in tomato [89,90]. In another study, S. cereale was grown as a cover crop and desiccated to stay as mulch one week before planting tomato. However, in this study, additional weed control measures were required to achieve satisfactory weed control [101]. In another study, cover crops such as T. incarnatum and $V$. villosa effectively controlled the weeds in tomato production but did not improve the tomato yield [102].

Among several cover species, the most effective for weed control in cabbage (Brassica oleracea var. capitata) were S. bicolor, sudangrass (Sorghum sudanense (P) Stapf.), and V. villosa, which caused the highest decrease in weed biomass and density [50]. Cover crops were effective in suppressing weeds 
such as A. retroflexus, European heliotrope (Heliotropium europaeum L.), P. oleraceae, field pennycress (Thlaspi arvense L.), annual sow thistle (Sonchus arvensis L.), black nightshade (Solanum nigrum L.), shepherd's-purse (Capsella bursa-pastoris (L.) Medik), C. album, sun spurge (Euphorbia helioscopia L.), wild mustard (Sinapis arvensis L.), etc., for almost two months. Weed control by V. villosa doubled the kale (Brassica oleracea L. var. acephala DC) yield compared to untreated control [50]. In cucumber production, the physical pressure and allelopathic effects of (S. bicolor $\times$ S. sudanense.) and S. cereale helped to cause a more than $80 \%$ decrease in weed densities [14]. V. villosa was also effective in controlling weeds but it yielded similar to control treatment. Nevertheless, S. cereale and S. bicolor $\times$ S. sudanense significantly increased the cucumber yield over control [14].

Lettuce is extensively used as a salad as well as in the making of rolls, wraps, sandwiches and several other recipes. As lettuce is mostly consumed as fresh leaves, non-chemical pest control is more important for this vegetable crop. Along with other non-chemical methods, cover crops have also been investigated for weed control in lettuce fields [17]. For example, the cover crop of cowpea (V. unguiculata (L.) Walp.) (grown in summer and then either kept as mulch or incorporated in the soil during fall) had very few weed species and higher lettuce yields compared to the other cover crop, S. vulgare, or the fallow treatment [17]. In pepper production, the cover crop species with the highest competitiveness against weeds were oat (Avena sativa L.), L. multiflorum, common vetch (Vicia sativa L.) and V. villosa [103]. By the end of the first and second months of cover crop incorporation, the $V$. villosa had the highest weed suppression (70\% or higher) and the plots with the same cover crop had the highest pepper yield [103]. Similarly, cowpea as a cover crop was also effective in weed control in pepper production, along with an increase in the growth and biomass production of pepper plants [104].

Ladino clover (Trifolium repens L.) as a cover crop residue was effective to suppress weeds in squash (Cucurbita maxima Duch.) at four weeks after planting; however, the effectiveness of the cover crop to affect weeds was diminished by the end of the second month of planting [105]. In another study, S. cereale and H. vulgare as cover crops in sugarbeet (Beta vulgaris L.) suppressed weeds such as D. sanguinalis, hooked bristlegrass [Setaria verticillata (L.) P.Beauv.], and E. crus-galli. This weed suppression was likely due to the allelopathic potential of $H$. vulgare and S. cereale [106]. V. villosa, $S$. cereal, or a mixture of these two cover crops was evaluated for their weed control ability in sweet corn. Either alone or in a mixture, the two cover crops suppressed the weeds and increased the yield of sweet corn [107]. Similarly, in another study, cover crops such as S. cereale, V. villosa, and wheat suppressed the early season weeds by nearly $50 \%$ in sweet corn. However, the cover crops were not effective in controlling sedge weeds. Wheat and S. cereale as a cover crop or a mixture of these with $V$. villosa had a negative effect on the yield of sweet corn [108].

Generally, it is assumed that weed control through cover crops in vegetables can be improved by using a mixture of cover crops belonging to different functional groups [109]. However, this may not always be true. For example, thirteen mixtures of cover crops were evaluated for their weed suppression in vegetables [110]. Mixtures of any cover crops poorly suppressed weeds if the mixture was a poor weed competitor or had poor mechanical desiccation. Importantly, individual cover crops that performed well with good establishment and weed competition also perform well when grown in mixtures. Cover crops that performed well both as individual crops and in a mixture were H. vulgare, S. cereale, V. villosa, and T. incarnatum, and these were subsequently used for weed control in tomato [110]. In another study, the use of cover crops in no-till planted vegetables could highly decrease the emergence of hairy nightshade (Solanum sarrachoides Sendtn.) and Powell's amaranth (Amaranthus powellii S.Watson) [111].

In contrast to conventional studies that determine the effect of cover crops on weed control in vegetables, some innovative techniques have also been investigated. For example, S. cereale cover crop inoculated with the plant beneficial fungus Trichoderma virens could control weeds in transplanted vegetables [112]. However, the number of such studies is very limited. 


\section{Integration of Cover Crops with Vegetable Crops}

There is a good opportunity to grow cover crops during the fallow period. The cover crops grown during the fallow period restrict the growth of weeds and seed establishment, hence providing weed-free fields for the upcoming vegetable crop season. For example, S. cereale, R. sativus and B. napus were strong inhibitors of weeds during the fallow period [113]. Cover crops are sown one to two months (or a few weeks) prior to the sowing of the main crop and then desiccated or killed. In some instances, cover crops and vegetables can grow together for a period of a few weeks. Along with the use of glyphosate, the use of mechanical killing of cover crops has also been proposed. Desiccation of cover crops may be easy when it is performed during flowering, or immediately before or after this period. Easy mechanical manipulation of cover crops such as H. vulgare, big flower vetch (Vicia grandiflora Scop.), S. cereale, T. subterraneum, crimson clover (Trifolium incarnatum L.), and V. villosa was achieved when crops were at bloom or post-bloom stage [114]. Cover crops were planted at the end of March and harvested in two months (end of May), and the main crops were planted within a week. Undercutter was a better terminator than field disks in reducing the biomass of grass weeds and increasing soybean and maize yields [115]. Cover crop management should be done with regard to the action mechanism of cover crops against weeds. For instance, if a cover crop has a high allelopathic activity, it may be mixed into the soil after its killing. However, if the cover crop suppresses weeds through its shading or a physical effect, then it may be left scattered on the soil after desiccation [116].

\section{Conclusions}

Non-chemical weed control is desired and it is important in vegetable crops for several reasons. With rising concerns regarding herbicide evolution in weeds and herbicide residue issues in the edible parts of vegetables, it is necessary to attempt weed control in vegetables through techniques such as cover crops. The discussion in this review shows that several cover crops suppress weeds in vegetable crops through their physical or allelopathic effects. Nevertheless, widespread implementation of cover crops across the world is lacking. Technological gaps and lack of site-specific experimentation may be reasons behind this. Local-scale experimentation and bridging the technological gaps can aid in a widespread utility of cover crops for sustainable weed control in vegetable production.

Funding: This research received no external funding.

Conflicts of Interest: The authors declare no conflicts of interest.

\section{References}

1. Oerke, E.C. Crop losses to pests. J. Agric. Sci. 2006, 144, 31-43. [CrossRef]

2. Ampong-Nyarko, K.; De Data, S.K. A Handbook for Weed Control in Rice; International Rice Research Institute: Manila, Philipines, 1991.

3. Pimentel, D.; McLaughlin, L.; Zepp, A.; Lakitan, B.; Kraus, T.; Kleinman, P.; Vancini, F.; Roach, W.J.; Graap, E.; Keeton, W.S.; et al. Environmental and economic impacts of reducing U.S. agricultural pesticide use. In Handbook of Pest Management in Agriculture; Pimentel, D., Ed.; CRC Press: Boca Raton, FL, USA, 1991; pp. 679-720.

4. Brown, B.; Hoshide, A.K.; Gallandt, E.R. An economic comparison of weed management systems used in small-scale organic vegetable production. Org. Agric. 2019, 9, 53-63. [CrossRef]

5. Schroeder, D.; Müller-Schärer, H.; Stintson, C.S.A. A European weed survey in 10 major crop systems to identify targets for biological control. Weed Res. 1993, 33, 449-458. [CrossRef]

6. Kropff, M.J.; Walter, H. EWRS and the Challenges for Weed Research at the Start of A New Millennium. Weed Res. 2000, 40,7-10. [CrossRef]

7. Jabran, K.; Chauhan, B.S. Overview and significance of non-chemical weed control. In Non-Chemical Weed Control; Elsevier: Cambridge, MA, USA, 2018; pp. 1-8. 
8. Dabney, S.M.; Murphree, C.E.; Triplett, G.B.; Grissinger, E.H.; Meyer, L.D.; Reinschmiedt, L.R.; Rhoton, F.E. Conservation production systems for silty uplands. In Proceedings of the 1993 Southern Conservation Tillage Conference for Sustainable Agriculture, Monroe, LA, USA, 17 June 1993; pp. 43-48.

9. Sainju, U.M.; Singh, B.P. Nitrogen storage with cover crops and nitrogen fertilization in tilled and non-tilled soils. Agron. J. 2008, 100, 619-627. [CrossRef]

10. Ngouajio, M.; Foko, J.; Fouejio, D. The critical period of weed control in common bean (Phaseolus vulgaris L.) in Cameroon. Crop Prot. 1997, 16, 127-133. [CrossRef]

11. Chandler, J.M.; Cooke, F.T. Economics of cotton losses caused by weeds. In Weeds of Cotton; McWhorter, C.G., Abernathy, J.R., Eds.; The Cotton Foundation: Memphis, TN, USA, 1992; pp. 85-116.

12. Vargas, R.; Fischer, W.B.; Kempen, H.M.; Wright, S.D. Cotton weed management. In Cotton Production; Johnson, M.S., Kerby, T.A., Hake, K.D., Eds.; UC DANR Pub: Oakland, CA, USA, 1996; pp. 187-202.

13. Teasdale, J.R. Contribution of cover crops to weed management in sustainable agricultural systems. J. Prod. Agric. 1996, 9, 475-479. [CrossRef]

14. Ngouajio, M.; Mennan, H. Weed populations and pickling cucumber (Cucumis sativus) yield under summer and winter cover crop systems. Crop Prot. 2005, 24, 521-526. [CrossRef]

15. Mennan, H.; Ngouajio, M.; Isik, D.; Kaya, E. Effect of alternative management systems on weed populations in hazelnut (Corylus avellana L.). Crop Prot. 2006, 25, 835-841. [CrossRef]

16. Norsworthy, J.K.; Malik, M.S.; Jha, P.; Riley, M.B. Suppression of Digitaria sanguinalis and Amaranthus palmeri using autumn-sown glucosinolate-producing cover crops in organically grown bell pepper. Weed Res. 2007, 47, 425-432. [CrossRef]

17. Ngouajio, M.; McGiffen, M.E., Jr.; Hutchinson, C.M. Effect of cover crop and management system on weed populations in lettuce. Crop Prot. 2003, 22, 57-64. [CrossRef]

18. Samarajeewa, K.B.D.P.; Horiuchi, T.; Oba, S. Finger millet (Eleucine corocana L. Gaertn.) as a cover crop on weed control, growth and yield of soybean under different tillage systems. Soil Till. Res. 2006, 90, 93-99. [CrossRef]

19. Teasdale, J.R.; Brandsaeter, L.O.; Calegari, A.; Neto, F.S.; Upadhyaya, M.K.; Blackshaw, R.E. Cover crops and weed management. In Non-chemical Weed Management: Principles, Concepts and Technology; Upadhyaya, M.K., Blackshaw, R.E., Eds.; CAB International: Cambridge, MA, USA, 2007; pp. 49-64.

20. Fisk, J.W.; Hesterman, O.B.; Shrestha, A.; Kells, J.J.; Harwood, R.R.; Squire, J.M.; Sheaffer, C.C. Weed suppression by annual legume cover crops in no-tillage corn. Agron. J. 2001, 93, 319-325. [CrossRef]

21. Reddy, K.N. Impact of rye cover crop and herbicides on weeds, yield, and net return in narrow-row transgenic and conventional soybean (Glycine max). Weed Technol. 2003, 17, 28-35. [CrossRef]

22. Teasdale, J.R.; Daughtry, C.S. Weed suppression by live and desiccated hairy vetch (Vicia villosa). Weed Sci. 1993, 41, 207-212. [CrossRef]

23. Altieri, M.A.; Lana, M.A.; Bittencourt, H.V.; Kieling, A.S.; Comin, J.J.; Lovato, P.E. Enhancing crop productivity via weed suppression in organic no-till cropping systems in Santa Catarina, Brazil. J. Sustain. Agric. 2011, 35, 855-869. [CrossRef]

24. Hoffman, M.L.; Weston, L.A.; Snyder, J.C.; Regnier, E.E. Allelopathic influence of germinating seeds and seedlings of cover crops on weed species. Weed Sci. 1996, 44, 579-584. [CrossRef]

25. Weiner, J. A new neighborhood model for annual-plant interference. Ecology 1982, 63, 1237-1241. [CrossRef]

26. Pike, D.R.; Stoller, E.W.; Wax, L.M. Modelling soybean growth and canopy apportionment in weed-soybean (Glycine max) competition. Weed Sci. 1990, 38, 522-527. [CrossRef]

27. Obopile, M.; Munthali, D.C.; Matilo, B. Farmers' knowledge, perceptions and management of vegetable pests and diseases in Botswana. Crop Prot. 2008, 27, 1220-1224. [CrossRef]

28. Akemo, M.C.; Regnier, E.E.; Bennett, M.A. Weed suppression in spring-sown rye (Secale cereale)-pea (Pisum sativum) cover crop mixes. Weed Technol. 2000, 14, 545-549. [CrossRef]

29. Roberts, H.A.; Hewson, R.T.; Ricketts, M.A. Weed competition in drilled summer lettuce. Hortic. Res. 1997, 17, 39-45.

30. Lanini, W.T.; Le Strange, M. Low-input management of weeds in vegetable fields. Calif. Agric. 1991, 45, 11-13.

31. Dusky, J.A.; Stall, W.M. Weed management practices for lettuce production using imazethapyr. In Proceedings of the 108th Florida State Horticultural Society, Lake Alfred, FL, USA, 22-24 October 1995; pp. 204-207. 
32. Shrefler, J.W.; Dusky, J.A.; Shilling, D.G.; Brecke B, J.; Sanchez, C.A. Effects of phosphorus fertility on competition between lettuce (Lactuca sativa L.) and spiny amaranth (Amaranthus spinosus L.). Weed Sci. 1995, 42, 556-560. [CrossRef]

33. Green-Tracewicz, E.; Page, E.R.; Swanton, C.J. Light quality and the critical period for weed control in soybean. Weed Sci. 2012, 60, 86-91. [CrossRef]

34. Morales-Payan, J.P.; Santos, B.M.; Stall, W.M.; Bewick, T.A. Effects of purple nutsedge (Cyperus rotundus) on tomato (Lycopersicon esculentum) and bell pepper (Capsicum annuum) vegetative growth and fruit yield. Weed Technol. 1997, 11, 672-676. [CrossRef]

35. Amador-Ramirez, M.D. Critical period of weed control in transplanted chilli pepper. Weed Res. 2002, 42, 203-209. [CrossRef]

36. Monaco, T.J.; Grayson, A.S.; Sanders, D.C. Influence of four weed species on the growth and quality of direct-seeded tomatoes (Lycopersicon esculentum). Weed Sci. 1981, 29, 394-397. [CrossRef]

37. Price, A.J.; Norsworthy, J.K. Cover crops for weed management in southern reduced-tillage vegetable cropping systems. Weed Technol. 2013, 27, 212-217. [CrossRef]

38. Dettmann, R.L.; Dimitri, C. Who's buying organic vegetables? Demographic characteristics of US consumers. J. Food Prod. Mark. 2009, 16, 79-91. [CrossRef]

39. Heap, I. Herbicide resistant weeds. In Integrated Pest Management; Springer: Dordrecht, Switzerland, 2014; pp. 281-301.

40. Pala, F.; Mennan, H. Socio-economic and environmental effects of glyphosate consumption. In Proceedings of the 3rd Anatolian International Congress of Applied Sciences, Diyarbakir, Turkey, 28-29 December 2019.

41. Coombs, C.; Lauzon, J.D.; Deen, B.; Van Eerd, L.L. Legume cover crop management on nitrogen dynamics and yield in grain corn systems. Field Crops Res. 2017, 201, 75-85. [CrossRef]

42. Sturm, D.J.; Peteinatos, G.; Gerhards, R. Contribution of allelopathic effects to the overall weed suppression by different cover crops. Weed Res. 2018, 58, 331-337. [CrossRef]

43. Akbari, P.; Herbert, S.J.; Hashemi, M.; Barker, A.V.; Zandvakili, O.R. Role of Cover crops and planting dates for improved weed suppression and nitrogen recovery in no-till systems. Commun. Soil Sci. Plant Anal. 2019, 50, 1722-1731. [CrossRef]

44. Snapp, S.S.; Swinton, S.M.; Labarta, R.; Mutch, D.; Black, J.R.; Leep, R.; Nyiraneza, J.; O’Neil, K. Review and Interpretation: Evaluating Cover Crops for Benefits, Costs, and Performance within Cropping System Niches. Agron. J. 2005, 97, 322-332.

45. Couëdel, A.; Kirkegaard, J.; Alletto, L.; Justes, E. Crucifer-legume cover crop mixtures for biocontrol: Toward a new multi-service paradigm. Adv. Agron. 2019, 157, 55-139.

46. Creamer, N.G.; Bennett, M.A.; Stinner, B.R.; Cardina, J.; Regnier, E.E. Mechanisms of weed suppression in cover crop-based production systems. Am. Soc. Hortic. Sci. 1996, 31, 410-413. [CrossRef]

47. Reberg-Horton, S.C.; Grossman, J.M.; Kornecki, T.S.; Meijer, A.D.; Price, A.J.; Place, G.T.; Webster, T.M. Utilizing cover crop mulches to reduce tillage in organic systems in the southeastern USA. Renew. Agric. Food Syst. 2012, 27, 41-48. [CrossRef]

48. Mirsky, S.B.; Ryan, M.R.; Teasdale, J.R.; Curran, W.S.; Reberg-Horton, C.S.; Spargo, J.T.; Wells, M.S.; Keene, C.L.; Moyer, J.W. Overcoming weed management challenges in cover crop-based organic rotational no-till soybean production in the eastern United States. Weed Technol. 2013, 27, 193-203. [CrossRef]

49. Mennan, H.; Ngouajio, M.; Isık, D.; Kaya, E. Effects of alternative winter cover cropping systems on weed suppression in organically grown tomato (Solanum lycopersicum). Phytoparasitica 2009, 37, 385-396. [CrossRef]

50. Mennan, H.; Ngouajio, M.; Kaya, E.; Isık, D. Weed management in organically grown kale using alternative cover cropping systems. Weed Technol. 2009, 23, 81-88. [CrossRef]

51. Hayden, Z.D.; Brainard, D.C.; Henshaw, B.; Ngouajio, M. Winter annual weed suppression in rye-vetch cover crop mixtures. Weed Technol. 2012, 26, 818-825. [CrossRef]

52. Lawley, Y.E.; Teasdale, J.R.; Weil, R.R. The mechanism for weed suppression by a forage radish cover crop. Agron. J. 2012, 104, 205-214. [CrossRef]

53. Brennan, E.B.; Smith, R.F. Winter cover crop growth and weed suppression on the central coast of California. Weed Technol. 2005, 19, 1017-1024. [CrossRef]

54. Boyd, N.S.; Brennan, E.B.; Smith, R.F.; Yokota, R. Effect of seeding rate and planting arrangement on rye cover crop and weed growth. Agron. J. 2009, 101, 47-51. [CrossRef] 
55. Cressman, S.T.; Page, E.R.; Swanton, C.J. Weeds and the red to far-red ratio of reflected light: Characterizing the influence of herbicide selection, dose, and weed species. Weed Sci. 2011, 59, 424-430. [CrossRef]

56. Rajcan, I.; Chandler, K.J.; Swanton, C.J. Red-far-red ratio of reflected light: A hypothesis of why early-season weed control is important in corn. Weed Sci. 2004, 52, 774-778. [CrossRef]

57. Mirsky, S.B.; Gallandt, E.R.; Mortensen, D.A.; Curran, W.S.; Shumway, D.L. Reducing the germinable weed seedbank with soil disturbance and cover crops. Weed Res. 2010, 50, 341-352. [CrossRef]

58. Moonen, A.C.; Barberi, P. Size and composition of the weed seedbank after 7 years of different cover-crop-maize management systems. Weed Res. 2004, 44, 163-177. [CrossRef]

59. Mirsky, S.B.; Curran, W.S.; Mortenseny, D.M.; Ryany, M.R.; Shumway, D.L. Timing of cover-crop management effects on weed suppression in no-till planted soybean using a roller-crimper. Weed Sci. 2011, 59, 380-389. [CrossRef]

60. Brennan, E.B.; Boyd, N.S.; Smith, R.F.; Foster, P. Seeding rate and planting arrangement effects on growth and weed suppression of a legume-oat cover crop for organic vegetable systems. Agron. J. 2009, 101, 979-988. [CrossRef]

61. Jabran, K.; Mahajan, G.; Sardana, V.; Chauhan, B.S. Allelopathy for weed control in agricultural systems. Crop Prot. 2015, 72, 57-65. [CrossRef]

62. Jabran, K. Manipulation of Allelopathic Crops for Weed Control, 1st ed.; Springer Nature International Publishing: Cham, Switzerland, 2017.

63. Jabran, K. Rye allelopathy for weed control. In Manipulation of Allelopathic Crops for Weed Control; Springer: Cham, Switzerland, 2017; pp. 49-56.

64. Tabaglio, V.; Marocco, A.; Schulz, M. Allelopathic cover crop of rye for integrated weed control in sustainable agroecosystems. Ital. J. Agron. 2013, 8, e5. [CrossRef]

65. Chase, W.R.; Nair, M.G.; Putnam, A.R. 2, 2'-oxo-1, 1'-azobenzene: Selective toxicity of rye (Secale cereale L.) allelochemicals to weed and crop species: II. J. Chem. Ecol. 1991, 17, 9-19. [CrossRef] [PubMed]

66. Yenish, J.P.; Worsham, A.D.; Chilton, W.S. Disappearance of DIBOA-glucoside, DIBOA, and BOA from rye (Secale cereale L.) cover crop residue. Weed Sci. 1995, 43, 18-20. [CrossRef]

67. Haramoto, E.R.; Gallandt, E.R. Brassica cover cropping: I. Effects on weed and crop establishment. Weed Sci. 2005, 53, 695-701. [CrossRef]

68. Petersen, J.; Belz, R.; Walker, F.; Hurle, K. Weed suppression by release of isothiocyanates from turnip-rape mulch. Agron. J. 2001, 93, 37-43. [CrossRef]

69. Kunz, C.; Sturm, D.J.; Varnholt, D.; Walker, F.; Gerhards, R. Allelopathic effects and weed suppressive ability of cover crops. Plant Soil Environ. 2016, 62, 60-66.

70. Williams, M.M.; Mortensen, D.A.; Doran, J.W. Assessment of weed and crop fitness in cover crop residues for integrated weed management. Weed Sci. 1998, 46, 595-603. [CrossRef]

71. Krogh, S.S.; Mensz, S.J.; Nielsen, S.T.; Mortensen, A.G.; Christophersen, C.; Fomsgaard, I.S. Fate of benzoxazinone allelochemicals in soil after incorporation of wheat and rye sprouts. J. Agric. Food Chem. 2006, 54, 1064-1074. [CrossRef]

72. Lovett, J.; Hoult, A. Allelopathy and Self-Defense in Barley. ACS Publ. 1995, 170-183. [CrossRef]

73. Oueslati, O.; Ben-Hammoudam, H.; Ghorbel, M.; El Gazzeh, M.; Kremer, R. Role of phenolic acids in expression of barley (Hordeum vulgare) autotoxicity. Allelopath. J. 2009, 23, 157-166.

74. Uddin, M.R.; Park, S.U.; Dayan, F.E.; Pyon, J.Y. Herbicidal activity of formulated sorgoleone, a natural product of sorghum root exudate. Pest Manag. Sci. 2014, 70, 252-257. [CrossRef] [PubMed]

75. Belz, R.G.; Hurle, K. Differential exudation of two benzoxazinoids one of the determining factors for seedling allelopathy of Triticeae species. J. Agric. Food Chem. 2005, 53, 250-261. [CrossRef] [PubMed]

76. Wu, H.; Pratley, J.; Lemerle, D.; Haig, T. Evaluation of seedling allelopathy in 453 wheat (Triticum aestivum) accessions against annual ryegrass (Lolium rigidum) by the equal compartment-agar method. Crop Pasture Sci. 2000, 51, 937-944. [CrossRef]

77. Brown, P.; Morra, M. Hydrolysis products of glucosinolates in Brassica napus tissues as inhibitors of seed germination. Plant Soil 1996, 181, 307-316. [CrossRef]

78. Vaughn, S.F.; Boydston, R.A. Volatile allelochemicals released by crucifer green manures. J. Chem. Ecol. 1997, 23, 2107-2116. [CrossRef]

79. Inderjit. Plant phenolics in allelopathy. Bot. Rev. 1996, 62, 186-202. [CrossRef] 
80. Xuan, T.D.; Hong, N.H.; Khanh, T.D.; Eiji, T.; Tawata, S.; Fukuta, M. Utilization of plant allelopathy for biological control of weeds and plant pathogens in rice. In Proceedings of the Fourth World Congress on Allelopathy, Wagga Wagga, Australia, 21-26 August 2005.

81. Xuan, T.D.; Chikara, J.; Ogushi, Y.; Tsuzuki, E.; Terao, H.; Khanh, T.D.; Matsuo, M. Application of kava (Piper methysticum L.) root as potential herbicide and fungicide. Crop Prot. 2003, 22, 873-881. [CrossRef]

82. Norsworthy, J.K.; Riar, D.; Jha, P.; Scott, R.C. Confirmation, control, and physiology of glyphosate-resistant giant ragweed (Ambrosia trifida) in Arkansas. Weed Technol. 2011, 25, 430-435. [CrossRef]

83. Bernstein, E.R.; Stoltenberg, D.E.; Posner, J.L.; Hedtcke, J.L. Weed community dynamics and suppression in tilled and no-tillage transitional organic winter rye-soybean systems. Weed Sci. 2014, 62, 125-137. [CrossRef]

84. Dube, E.; Chiduza, C.; Muchaonyerwa, P. Conservation agriculture effects on soil organic matter on a Haplic Cambisol after four years of maize-oat and maize-grazing vetch rotations in South Africa. Soil Till. Res. 2012, 123, 21-28. [CrossRef]

85. Finney, D.M.; Creamer, N.G.; Schultheis, J.R.; Wagger, M.G.; Brownie, C. Sorghum sudangrass as a summer cover and hay crop for organic fall cabbage production. Renew. Agric. Food Syst. 2009, 24, 225-233. [CrossRef]

86. Moran, P.; Greenberg, S. Winter cover crops and vinegar for early-season weed control in sustainable cotton. J. Sustain. Agric. 2008, 32, 483-506. [CrossRef]

87. Silva, E.M. Screening five fall-sown cover crops for use in organic no-till crop production in the upper midwest. Agroecol. Sustain. Food Syst. 2014, 38, 748-763. [CrossRef]

88. Alcántara, C.; Pujadas, A.; Saavedra, M. Management of Sinapis alba subsp. mairei winter cover crop residues for summer weed control in southern Spain. Crop Prot. 2011, 30, 1239-1244.

89. Campiglia, E.; Caporali, F.; Radicetti, E.; Mancinelli, R. Hairy vetch (Vicia villosa Roth.) cover crop residue management for improving weed control and yield in no-tillage tomato (Lycopersicon esculentum Mill.) production. Eur. J. Agron. 2010, 33, 94-102. [CrossRef]

90. Campiglia, E.; Mancinelli, R.; Radicetti, E.; Caporali, F. Effect of cover crops and mulches on weed control and nitrogen fertilization in tomato (Lycopersicon esculentum Mill.). Crop Prot. 2010, 29, 354-363. [CrossRef]

91. Grünwald, N.; Hu, S.; Van Bruggen, A. Short-term cover crop decomposition in organic and conventional soils: Characterization of soil C, N, microbial and plant pathogen dynamics. Eur. J. Plant Pathol. 2000, 106, 37-50. [CrossRef]

92. Masiunas, J.B. Production of vegetables using cover crop and living mulches-A review. J. Veg. Crop Prod. 1998, 4, 11-31.

93. Mulvaney, M.J.; Price, A.J.; Wood, C.W. Cover crop residue and organic mulches provide weed control during limited-input no-till collard production. J. Sustain. Agric. 2011, 35, 312-328. [CrossRef]

94. Kruidhof, H.M.; Bastiaans, L.; Kropff, M.J. Cover crop residue management for optimizing weed control. Plant Soil 2009, 318, 169-184. [CrossRef]

95. Baumgartner, K.; Steenwerth, K.L.; Veilleux, L. Cover-crop systems affect weed communities in a California vineyard. Weed Sci. 2008, 56, 596-605. [CrossRef]

96. Steinmaus, S.; Elmore, C.L.; Smith, R.J.; Donaldson, D.; Weber, E.A.; Roncoroni, J.A.; Miller, P.R.M. Mulched cover crops as an alternative to conventional weed management systems in vineyards. Weed Res. 2008, 48, 273-281. [CrossRef]

97. Brainard, D.C.; Bellinder, R.R.; Kumar, V. Grass-legume mixtures and soil fertility affect cover crop performance and weed seed production. Weed Technol. 2011, 25, 473-479. [CrossRef]

98. Mirsky, S.B.; Ryan, M.R.; Curran, W.S.; Teasdale, J.R.; Maul, J.; Spargo, J.T.; Moyer, J.; Grantham, A.M.; Weber, D.; Way, T.R.; et al. Conservation tillage issues: Cover crop-based organic rotational no-till grain production in the mid-Atlantic region, USA. Renew. Agric. Food Syst. 2012, 27, 31-40. [CrossRef]

99. Stivers-Young, L. Growth, nitrogen accumulation, and weed suppression by fall cover crops following early harvest of vegetables. HortScience 1998, 33, 60-63.

100. Masiunas, J.B.; Weston, L.A.; Weller, S.C. The impact of rye cover crops on weed populations in a tomato cropping system. Weed Sci. 1995, 43, 318-323. [CrossRef]

101. Caamal-Maldonado, J.A.; Jiménez-Osornio, J.J.; Torres-Barragán, A.; Anaya, A.L. The use of allelopathic legume cover and mulch species for weed control in cropping systems. Agron. J. 2001, 93, 27-36. [CrossRef]

102. Teasdale, J.R.; Abdul-Baki, A.A. Comparison of mixtures vs. monocultures of cover crops for fresh-market tomato production with and without herbicide. HortScience 1998, 33, 1163-1166. [CrossRef] 
103. Isik, D.; Kaya, E.; Ngouajio, M.; Mennan, H. Weed suppression in organic pepper (Capsicum annuum L.) with winter cover crops. Crop Prot. 2009, 28, 356-363. [CrossRef]

104. Hutchinson, C.M.; McGiffen, M.E. Cowpea cover crop mulch for weed control in desert pepper production. HortScience 2000, 35, 196-198. [CrossRef]

105. Galloway, B.A.; Weston, L.A. Influence of cover crop and herbicide treatment on weed control and yield in no-till sweet corn (Zea mays L.) and pumpkin (Cucurbita maxima Duch.). Weed Technol. 1996, 10, 341-346. [CrossRef]

106. Dhima, K.V.; Vasilakoglou, I.B.; Eleftherohorinos, I.G.; Lithourgidis, A.S. Allelopathic potential of winter cereal cover crop mulches on grass weed suppression and sugarbeet development. Crop Sci. 2006, 46, 1682-1691. [CrossRef]

107. Carrera, L.M.; Abdul-Baki, A.A.; Teasdale, J.R. Cover crop management and weed suppression in no-tillage sweet corn production. HortScience 2004, 39, 1262-1266. [CrossRef]

108. Burgos, N.R.; Talbert, R.E. Weed control and sweet corn (Zea mays var. rugosa) response in a no-till system with cover crops. Weed Sci. 1996, 44, 355-361. [CrossRef]

109. Ranaldo, M.; Carlesi, S.; Costanzo, A.; Bàrberi, P. Can weed management in vegetable systems be improved by cover crop species mixtures? Step 2: Field implementation. In Proceedings of the 7th International Weed Science Congress, Prague (CZ), Czech, 19-25 June 2016.

110. Creamer, N.G.; Bennett, M.A.; Stinner, B.R. Evaluation of cover crop mixtures for use in vegetable production systems. HortScience 1997, 32, 866-870. [CrossRef]

111. Peachey, R.E.; William, R.D.; Mallory-Smith, C. Effect of no-till or conventional planting and cover crops residues on weed emergence in vegetable row crop. Weed Technol. 2004, 18, 1023-1030. [CrossRef]

112. Héraux, F.M.; Hallett, S.G.; Weller, S.C. Combining Trichoderma virens-inoculated compost and a rye cover crop for weed control in transplanted vegetables. Biol. Control 2005, 34, 21-26. [CrossRef]

113. Kruidhof, H.M.; Bastiaans, L.; Kropff, M.J. Ecological weed management by cover cropping: Effects on weed growth in autumn and weed establishment in spring. Weed Res. 2008, 48, 492-502. [CrossRef]

114. Creamer, N.G.; Plassman, B.; Bennett, M.A.; Wood, R.K.; Stinner, B.R.; Cardina, J. A method for mechanically killing cover crops to optimize weed suppression. Am. J. Altern. Agric. 1995, 10, 157-162. [CrossRef]

115. Wortman, S.E.; Francis, C.A.; Bernards, M.A.; Blankenship, E.E.; Lindquist, J.L. Mechanical termination of diverse cover crop mixtures for improved weed suppression in organic cropping systems. Weed Sci. 2013, 61, 162-170. [CrossRef]

116. Tursun, N.; Işık, D.; Demir, Z.; Jabran, K. Use of living, mowed, and soil-incorporated cover crops for weed control in apricot orchards. Agronomy 2018, 8, 150. [CrossRef] 